\title{
Basic and clinical aspects of osteoporosis in inflammatory bowel disease
}

\author{
Lorena Rodríguez-Bores, Josué Barahona-Garrido, Jesús K Yamamoto-Furusho
}

Lorena Rodríguez-Bores, Josué Barahona Garrido, Jesús K Yamamoto-Furusho, IBD Clinic, Department of Gastroenterology, Instituto Nacional de Ciencias Médicas y Nutrición Salvador Zubirán. Vasco de Quiroga 15 colonia Sección XVI, Tlalpan, CP 14000, México

Correspondence to: Jesús $\mathrm{K}$ Yamamoto-Furusho, MD, PhD, Head of IBD Clinic, Department of Gastroenterology, Instituto Nacional de Ciencias Médicas y Nutrición Salvador Zubirán. Vasco de Quiroga 15 colonia Sección XVI, Tlalpan, CP 14000, México. kazuofurusho@hotmail.com

Telephone: +52-55-55733418-2705 Fax: $+52-55-56550942$

Received: August 26, $2007 \quad$ Revised: September 25, 2007

\begin{abstract}
Low bone mineral density and the increased risk of fracture in gastrointestinal diseases have a multifactorial pathogenesis. Inflammatory bowel disease (IBD) has been associated with an increased risk of osteoporosis and osteopenia and epidemiologic studies have reported an increased prevalence of low bone mass in patients with IBD. Certainly, genetics play an important role, along with other factors such as systemic inflammation, malnutrition, hypogonadism, glucocorticoid therapy in IBD and other lifestyle factors. At a molecular level the proinflammatory cytokines that contribute to the intestinal immune response in IBD are known to enhance bone resorption. There are genes influencing osteoblast function and it is likely that LRP5 may be involved in the skeletal development. Also the identification of vitamin $D$ receptors (VDRs) and some of its polymorphisms have led to consider the possible relationships between them and some autoimmune diseases and may be involved in the pathogenesis through the exertion of its immunomodulatory effects during inflammation. Trying to explain the physiopathology we have found that there is increasing evidence for the integration between systemic inflammation and bone loss likely mediated via receptor for activated nuclear factor kappa-B (RANK), RANK-ligand, and osteoprotegerin, proteins that can affect both osteoclastogenesis and T-cell activation. Although glucocorticoids can reduce mucosal and systemic inflammation, they have intrinsic qualities that negatively impact on bone mass. It is still controversial if all IBD patients should be screened, especially in patients with preexisting risk factors for bone disease. Available methods to measure BMD include single energy $x$-ray absorptiometry, DXA, quantitative computed tomography (QCT), radiographic absorptiometry, and ultrasound.
\end{abstract}

DXA is the establish method to determine BMD, and routinely is measured in the hip and the lumbar spine. There are several treatments options that have proven their effectiveness, while new emergent therapies such as calcitonin and teriparatide among others remain to be assessed.

\section{(C) 2007 WJG. All rights reserved.}

Key words: Inflammatory bowel disease; Osteoporosis

Rodríguez-Bores L, Barahona-Garrido J, YamamotoFurusho JK. Basic and clinical aspects of osteoporosis in inflammatory bowel disease. World J Gastroenterol 2007; 13(46): 6156-6165

http://www.wjgnet.com/1007-9327/13/6156.asp

\section{INTRODUCTION}

Patients with inflammatory bowel disease (IBD) are at increased risk of developing disorder in bone and mineral metabolism because of several factors, including the genetic influence, cytokine-mediated nature of the inflammatory bowel disease, the intestinal malabsorption resulting from disease activity or from extensive intestinal resection and the use of glucocorticoids to control disease activity. Apparently these disturbances may also be seen since childhood, and environmental factors such as malnutrition, immobilization, low body mass index (BMI), smoking and hypogonadism may also play a contributing role in the pathogenesis of bone loss. In IBD several studies demonstrate a negative correlation between bone mineral density (BMD) and glucocorticoid use, though there is evidence that may support the opposite. In order to answer the questions about the pathogenesis, we first have to determine the factors that are involved in this extraintestinal complication. The aim of this paper is to review the basic and molecular aspects with the clinical and therapeutic features and have an overview about the trends of the bone disease related to IBD.

\section{EPIDEMIOLOGY}

Bone mineral density is decreased in a proportion of subjects with IBD as shown by epidemiological studies. The current understanding about IBD and BMD is that 
the overall risk of fracture may be slightly increased in IBD patients. IBD has been associated with an increased risk of osteoporosis and osteopenia and epidemiologic studies have reported an increased prevalence of low bone mass in patients with IBD. The prevalence rates from $2 \%$ to $30 \%$ for osteoporosis (OP), from $40 \%$ to $50 \%$ for osteopenia ${ }^{[1]}$ and the overall prevalence of low bone mineral density is estimated in $15 \%$. A populationbased study compared IBD patients with the general population and reported similar increases in the fracture risk between Crohn's disease (CD) and Ulcerative colitis $(\mathrm{UC})^{[2]}$ and in comparison to control patients, similar to what other population-based studies have reported ${ }^{[3,4]}$. Some series have reported that in newly diagnosed IBD patients a reduced BMD has been found and this prevalence is slightly higher in patients with $\mathrm{CD}^{[3,5]}$ whereas approximately $15 \%$ of patients with $C D$ have osteoporosis ${ }^{[6]}$. There is contrasting data from a Danish case-control study where an increase in the risk of fracture among women with CD was seen, but not men with $\mathrm{CD}$ or patients with $\mathrm{UC}^{[7,8]}$, also another study reported that the overall fracture rate in UC was similar to that of control subjects ${ }^{[0]}$. In regard to age and gender as risk factors, elderly have the highest risk of fracturing and this increased risk is evident across all age groups ${ }^{[3]}$. Some case control studies have demonstrated that gender, age, and body weight are the major determinants of bone mineral density in patients with $\mathrm{CD}$. As in healthy individuals, the combined effect of these factors account for up to $50 \%$ of the variability in bone mineral density ${ }^{[10]}$. Male sex and increasing age were considered risk factors in predicting those with osteoporosis although most series report no significant difference between the genders.

Longitudinal studies show that the BMD changes are not excessive $e^{[11,12]}$ and there is no exclusive pattern of low BMD that involves spine of the hip. The risk of hip fracture is increased by $86 \%$ in patients with $\mathrm{CD}$ and by $40 \%$ in patients with $\mathrm{UC}^{[2]}$. However the hip has been reported more frequently affected than the spine ${ }^{[13,14]}$. In a study of Stockbrugger et al significant number of fractures in IBD patients as in the general osteoporotic are asymptomatic, about $14.2 \%$ of the fractures seem to be underreported ${ }^{[15]}$, though it is important to mention that osteoporosis occurrence is often underestimate ${ }^{[15]}$.

\section{GENETICS}

Low bone mineral density and the increased risk of fracture in all gastrointestinal diseases including IBD have a multifactorial pathogenesis. There are a number of factors that can lead to enhanced bone loss, these also include genetic factors.

\section{LRP5}

Because of the central role of osteoblasts in bone formation, it is easy to think there are genes influencing osteoblast function and it is likely that LRP5 may be involved in the skeletal development. The protein encoded by LRP5 is a member of the low-density lipoproteinreceptor $(L D L R)$ gene superfamily ${ }^{[16]}$ and is closely related to $L R P 6^{[17]}$. LRP5 is transcribed in human bone tissue as well as in numerous other tissues. There is convincing findings that deleterious (loss of function) mutations in LRP5 result in loss of function and cause bone defects such as the ones seen in pseudoglioma syndrome further supporting the critical role of this gene in skeletal integrity ${ }^{[18]}$. There is some data about the identification in normal healthy individuals of a gain of function mutation in the LDL receptor-related protein 5 (LPR5) gene resulting from a autosomal dominant high bone mass trait ${ }^{[19]}$ and this gain of function mutation described in LRP5 produces increased bone mass with no adverse effect on skeletal structure, contrasting the loss of function mutation that maps to the same genomic region that contains LRP5 causes the osteoporosis pseudoglioma syndrome ${ }^{[20]}$. Polymorphisms rs491347 rs1784235 could be important to human osteoporosis phenotypes and may be considered as possible susceptibility factors for osteoporosis and fractures in humans ${ }^{[21]}$. A Japanese study found that the A1330 V polymorphism may contribute to osteoporosis susceptibility ${ }^{[2]}$ and also was associated with reduced BMC and BMD values in healthy young Finnish men, providing evidence for the crucial role of LRP5 in peak bone mass acquisition ${ }^{[23]}$.

\section{VDR (Vitamin D receptor gene)}

The identification of vitamin D receptors (VDRs) in peripheral blood mononuclear cells sparked the early interest in vitamin $\mathrm{D}$ as an immune system regulator ${ }^{[24]}$. Vitamin D deficiency has been linked to several different diseases, including the immune system-mediated OP such as IBD. The association of VDR gene BsmI polymorphism with OP has been studied by several investigators ${ }^{[24-28]}$. In addition, TaqI, FokI and ApaI polymorphisms of the VDR gene have also been described ${ }^{[25]}$. Regarding OP, most data concern to the BsmI polymorphism of the vitamin $\mathrm{D}$ receptor (VDR) gene.

\section{Candidate genes}

There are other candidate genes that seem involved with bone loss. Estrogen receptor alpha (ER alpha) play an important role in increasing BMD via mechanical strain and muscle mass ${ }^{[22]}$. The results of studies regarding the association between some common polymorphisms of the aromatase gene and bone mineral density and the risk of osteoporotic fractures are recognized ${ }^{[30]}$. Thus, aromatase is also an attractive osteoporosis candidate gene. The gene encoding TGF $\beta 1$ is a strong functional candidate for genetic susceptibility to osteoporosis. Several polymorphisms have been identified in TGF $\beta 1$, and previous work has suggested that allelic variants of TGF $\beta 1$ may regulate BMD and susceptibility to osteoporotic fracture $^{[31]}$. During the last years, about 170 candidate genes have been published. There have been (e.g., VDR, ER- $\alpha$, and COL1A1), as well as novel genes recently discovered to be important in bone and mineral metabolism. The newly studied genes include a big list CYP17 (17-hydroxylase) ${ }^{[32]}$, CYP1B1 (cytochrome P450) ${ }^{[33]}$, DBP (vitamin D-binding protein) ${ }^{[34]}$, GH1 (growth hormone 1) ${ }^{[35]}$, GnRH (gonadotropin-releasing 
hormone $1^{[35]}$ ), IGF- II (insulin-like growth factor II $)^{[37]}$, LEPR (leptin receptor) ${ }^{[38]}$, LRP5 (low-density lipoprotein receptor-related protein 5) ${ }^{[39]}$, BMP2 (bone morphogenetic protein 2$)^{[40]}$, CCR2 (chemokine) ${ }^{[41]}$, CLCN7 (chloride channel 7) ${ }^{[42]}$, COMT (catechol-O-methyltransferase) ${ }^{[43]}$, CTSK (cathepsin K) ${ }^{[44]}$, DRD4 (dopamine receptor D4) ${ }^{[45]}$, I -TRAF (TRAF family member-associated NF- $\mathrm{NB} \mathrm{B}$ activator) ${ }^{[46]}$, LCT (lactase) ${ }^{[47]}$, MIF (macrophage migration inhibitory factor) ${ }^{[48]}$, MMP-1 (matrix metalloproteinase $1)^{[49]}$, among many others, but their relationship with inflammation as a possible mechanism of osteoporosis still is not clear and the interaction with IBD bone disease has not been elucidated. The mechanisms involved and the potential usefulness of those genetic data in the prevention and management of osteoporosis need further investigation, also to determine the direct relation with IBD.

\section{PATHOPHYSIOLOGY}

Inflammation has now moved to the center of the physiopathologic mechanisms involved in the process of bone loss in IBD, there has been a considerable increase in knowledge surrounding the genetic determinants of osteoporosis. As well as genetic markers are potentially helpful in identifying high risk patients, the genetic variations of cytokines plays a key role in the regulation of the inflammatory response. Several studies are focused trying to identify genetic risk factors for rapid bone loss in IBD patients as a model of disease and inflammationassociated bone loss. Evidence accumulated in the past years support that interleukin 6 (IL-6) is a pathogenic factor in osteoporosis that results from the loss of either male or female sex steroids and have implicated IL-6 in the physiopathology of several other diseases caused by increased osteoclastic bone resorption including diseases such as Rheumatoid arthritis ${ }^{[50]}$. Genetic variations in the IL-6 and interleukin 1 receptor antagonist (IL-1ra) gene identify IBD patients at risk for increased bone loss. Allele status of the IL-1ra, IL-6, heat shock protein 70-2 and 70-hom (hsp 70-2, hsp hom) gene has been typed and correlated with clinical course of IBD and extent of bone $\operatorname{loss}^{[51]}$. These variations are independent determinants of bone loss in the setting of IBD, and have been identified as independent predictors of bone loss in the setting of postmenopausal osteoporosis, suggesting that IL-6 and IL-1 ra determine the response of bone to different stressors such as the hypoestrogenic state or systemic inflammation ${ }^{[52,53]}$. Apparently, estrogen loss results in increased production of IL-6 by ex vivo bone marrow cell cultures and increased production of IL- 6 follows the withdrawal of estradiol from primary culture ${ }^{[54,55]}$. It seems that IL-6 is responsible for increased bone resorption after loss of sex steroids and that gonadectomy prevents the increase in osteoclastogenesis in bone marrow and the increase in the number of osteoclasts in sections of trabecular bone ${ }^{[56]}$. The cytokines IL- 1 ra and IL- 6 also have a central role in the paracrine stimulation of osteoclast development and regulation of the process of bone resorption ${ }^{[50,55]}$. Increasing evidence suggests that IL-6 type cytokines also promote the development of osteoblasts ${ }^{[50]}$. It has been observed that the carriage of the A2 allele of the IL-1ra gene is associated with reduced bone loss ${ }^{[52]}$.

The interleukine-2 (IL-2) deficient mouse model of colitis is known to develop both osteopenia and colitis. Osteopenia was not evident in IL-2 deficient mouse cross-bred to be T-cell deficient, and osteopenia could be induced in T-cell-deficient mice by adoptive transfer of $\mathrm{T}$ cells from IL-2 deficient mice ${ }^{[57]}$. These data suggest that activated $\mathrm{T}$ cells are critical for mediating the osteopenia.

\section{OPG-RANK-RANKL system}

The receptor activator of nuclear factor $\kappa \mathrm{B}$ ligand (RANKL) osteoprotegerin (OPG) system represents a potential link between inflammation and bone homeostasis and also an example of inflammation-mediated osteopenia such as IBD-associated osteopenia. The balance between RANKL and OPG (the soluble decoy receptor preventing ligation of RANKL) is of major importance to the regulation of osteoclastogenesis. The interaction of RANK on the surface of osteoclasts with its ligand RANKL induces osteoclastogenesis and conversely the interaction with the osteoblast derived soluble decoy receptor, osteoprotegerin $(\mathrm{OPG})^{[58]}$ blocks RANKRANKL interaction inhibiting osteoclasts formation. Whether compounds stimulate RANK ligand or OPG will affect whether they induce or inhibit osteoclastogenesis. Pro-inflammatory cytokines induce RANKL and promote bone resorption with consecutive bone loss. Activated T cells can directly trigger osteoclastogenesis through RANKL leading to bone loss while OPG can block those effects ${ }^{[59-61]}$. Increased OPG levels may represent a continuing homeostatic response, attempting to reverse established osteopenia and RANKL driven osteoclastogenesis, thus maintaining normal bone mass. Inflammation seems to play an important role in the regulation of the OPG-RANK-RANKL system. To correlate it with chronic inflammatory states comparable to IBD, there have been some reports that show a direct correlation between serum OPG and erythrocyte sedimentation rate and a score of disease activity in patients with rheumatoid arthritis ${ }^{[62]}$. Soluble RANKL as well as OPG levels are elevated in rheumatoid arthritis, while high OPG and decreased RANKL levels have been reported in primary biliary cirrhosis ${ }^{[63,64]}$. Some of the osteoclastogenic factors released from the IBD mucosa (for example IL-1, IL-6 and TNF $\alpha$ ) are thought to function indirectly via specific receptors on stromal osteoblastic cells to enhance RANKL expression ${ }^{[60,65,66]}$. Data suggests that OPG may be a protective host response that partially offsets the adverse skeletal effect created by the inflammation state. Moshen et al ${ }^{[67]}$ described the alterations in the RANKL/OPG system in IBD and its relationship to decreased $\mathrm{BMD}$. It has been demonstrated increased plasma levels of OPG as well as increased release from the inflamed colon in IBD, suggesting the macrophages and dendritic cells as colonic source of OPG in IBD. Apparently, no correlation was evident between corticosteroid and serum OPG ${ }^{[63]}$ contrasting partially with other findings. 


\section{Corticosteroids}

The controversial participation of glucocorticoid (GC) therapy in the pathogenesis of bone loss in IBD still has gaps to be fulfilled. It seems that there is an important relationship between dosage, duration and pattern of GC therapy and these factors are related to the incidence of pathological fractures ${ }^{[68]}$. Some studies indicate that fractures are present in 30\%-50\% of patients on GC therapy for chronic diseases ${ }^{[69]}$ and several studies have demonstrated that dosage is associated with $\mathrm{BMD}^{[51,70-73]}$. On the other hand, several studies have reported the opposite $^{[8,13]}$.

The epidemiological data on fracture risk and bone loss in GC therapy do not distinguish the effects of drug and the effects of the underlying disease. It is known, for example, in rheumatoid arthritis, the risk of fracture is increased even in the absence of GC exposure, also it has been observed that osteoporosis is rapidly developed in recently diagnosed Crohn's disease without any effect of corticosteroids in the follow up. One study showed that the prevalence of osteoporosis in pediatric patients with IBD is approximately the same as in adult patients, showing that osteoporosis was already present before steroid treatment ${ }^{[74]}$. Contrasting data from other studies show that the extent of bone loss was no correlated to clinical severity of disease or application of corticosteroids ${ }^{[75-77]}$. The participation of GC in the pathophisiology of bone loss is complex. GCs influence the production and action of hormones that regulate bone and calcium metabolism and also have direct effects of GCs on bone. GCs increase the expression of receptor activator of nuclear factor $\kappa \mathrm{B}$ ligand (RANK-L) and decrease the expression of its soluble decoy receptor osteoprotegerin (OPG) in stromal and osteoblastic cells ${ }^{[78]}$ and also enhance the expression of macrophage colony-stimulating factor (M-CSF), which in the presence of RANK-L induces osteoclastogene sis $^{[78-80]}$. GCs have direct effects on osteoclasts also by suppressing the expression of an autocrine cytokine, such as interferon I, that normally exerts inhibitory effects on osteoclastogenesis ${ }^{[80]}$. Also they inhibit the function of mature osteoblasts and suppress the synthesis of insulin-like growth factor- I, an agent that enhances bone formation ${ }^{[78,79]}$.

The wingless-type (Wnt) signaling has emerged as a novel, key pathway for promoting osteoblastogenesis. The Wnt signal transduction comprises three intracellular pathways: the canonical pathway, the Wnt/planar-cellpolarity (PCP) pathway, and the Wnt $/ \mathrm{Ca}^{2+}$ pathway ${ }^{[81,82]}$. Wnt signals are extracellularly regulated by several secreted antagonists including secreted frizzled-related protein (sFRP), Cerberus, Wnt inhibitory factor-1 (WIF-1), and dickkopf $(\mathrm{Dkk})^{[83]}$. Some studies strongly suggest that the canonical pathway plays a central role in promoting bone formation ${ }^{[8-86]}$. Some groups have reported that glucocorticoid enhances the expression of dickkopf-1 (Dkk-1) in cultured human osteoblasts ${ }^{[87]}$ by suppressesing the canonical Wnt signal ${ }^{[88]}$.

\section{DIAGNOSIS}

\section{Diagnosis of osteoporosis in IBD patients}

Due to the low absolute risk of fracture remains contro- versial if all IBD patients should be screened, but it is suggested for avoiding the complications of osteoporosis, especially in patients with a preexisting bone disease, older than 65 , and with risk factors for low bone mass as longterm steroid therapy (prednisone $5 \mathrm{mg}$ daily for 6 mo or more ${ }^{[88-91]}$.

Both, the American College of Gastroenterology (ACG) and American Gastroenterological Association (AGA) issued position papers to offer guidance to the practicing clinician in the diagnosis and management of bone loss in IBD. These position papers recommended the selective screening of IBD patients with dual energy $\mathrm{x}$-ray absorptiometry (DXA) scanning, and the criteria for DXA screening included: postmenopausal state, ongoing corticosteroid treatment, cumulative prior use of corticosteroids exceeding 3 mo, history of low trauma fractures, and age over 60 . These criteria led to the detection of osteopenia or osteoporosis and initiation of specific therapies in the majority of patients ${ }^{[92]}$.

Available methods to measure BMD include single energy x-ray absorptiometry, DXA, quantitative computed tomography (QCT), radiographic absorptiometry, and ultrasound. DXA is the establish method to determine $\mathrm{BMD}$, and routinely is measured in the hip and the lumbar spine $^{[93]}$.

The $\mathrm{T}$ score was proposed by the World Health Organization (WHO) as the strongest determinant of fracture risk. $T$ score is defined as the number of standard deviations (SD) by which a given BMD measurement exceeds or falls below the normal mean BMD of healthy 30-year-old individuals (peak bone mass). A BMD that is up to $1 \mathrm{SD}$ below the peak bone mass is considered normal; between 1 to $2.49 \mathrm{SD}$ below peak BMD is considered as osteopenic and to have mild to moderate bone deficiency; and $\geqslant 2.5$ SD below the peak BMD are labeled osteoporotic and with marked bone deficiency. Individuals who have a fracture as a result of bone fragility are considered to have severe osteoporosis ${ }^{[33]}$. The $\mathrm{z}$ score is useful too, and is defined as the number of SDs by which a given BMD measurements exceeds or falls below the mean BMD of healthy individuals of the same age group. For the International Society for Clinical Densitometry (ISCD), z scores are preferred, and the WHO classification should not be applied in women before menopause and in men younger than $50^{[94]}$.

\section{TREATMENT OPTIONS}

\section{Calcium and vitamin $D$}

It is known that calcium and vitamin D are essential in the metabolism of bone and so multiple trials have studied their benefit as treatment of osteoporosis. The use of calcium or/and vitamin D or its analogues have shown, in 2 meta-analysis, 1 Cochrane Review, and in a large placebo-controlled study, to have a small benefit in $\mathrm{BMD}$ and a controversial age-dependant trend, and not totally clear reduction of bone fractures, specially of the spine, in postmenopausal women ${ }^{[95-98]}$. In a randomized, placebo-controlled trial in glucocorticoid-using patients with IBD, the intake of vitamin D $250 \mathrm{IU}$ and calcium $1000 \mathrm{mg} / \mathrm{d}$ had no significant benefit in bone density at 1 year of follow-up ${ }^{[99]}$. So, as described in a recent 
consensus report, the supplementation with calcium and vitamin $\mathrm{D}$ is accepted as a cost-effective medication, and essential but insufficient, in the prevention and treatment of osteoporosis. The dosage that showed best is calcium $1200 \mathrm{mg} / \mathrm{d}$ and vitamin D $800 \mathrm{IU} / \mathrm{d}$. The maximum benefit of calcium and vitamin $\mathrm{D}$ will generally be derived from combination therapy with an antiresorptive agent ${ }^{[100]}$.

\section{Bisphosphonates}

The group of this antiresorptive analogue of pyrophosphate includes etidronate, pamidronate, tiludronate, alendronate, risedronate, and ibandonate.

Both, alendronate and risedronate, have shown to be effective in increasing BMD and reducing fractures in spine, hip and wrist for the treatment of osteoporosis in postmenopausal women. In a systematic review, metaanalysis and double blind and randomized study, they reduce vertebral fractures by $30 \%$ to $50 \%$, with superiority for $70 \mathrm{mg}$ once-weekly alendronate than daily $5 \mathrm{mg}$ or once-weekly $35 \mathrm{mg}$ of risedronate, and with similar tolerability profiles, at 1 or 2 years ${ }^{[101-105]}$.

For the prevention and treatment of glucocorticoidinduced osteoporosis, in a randomized, double-blind, placebo-controlled, multicenter study, in patients receiving a minimum of $7.5 \mathrm{mg}$ prednisone or its equivalent for diverse pathologies, all receiving 800-1000 mg elemental calcium and 250-500 IU of vitamin D, alendronate at a dosage of 5 or $10 \mathrm{mg} / \mathrm{d}$ significantly increased bone density compared to placebo at 1 year and reduced the incidence of bone fractures too, at 2 years ${ }^{[106,107]}$.

In patients with moderate to high doses of corticoid therapy, a significant increase of BMD and a reduction of $70 \%$ in vertebral fracture risk was observed with risedronate $5 \mathrm{mg} / \mathrm{d}$ compared with the placebo group $(P=0.01)$. Risedronate was efficacious, irrespective of underlying disease and duration of corticosteroid therapy, and had a favorable safety profile, with a similar incidence of upper gastrointestinal adverse events to placebo ${ }^{[108,109]}$.

Etidronate have shown to be superior to placebo for increasing BMD in lumbar spine and femoral neck, and reducing incidence of vertebral fractures with no effect in non-vertebral fractures in postmenopausal women ${ }^{[110]}$.

A meta-analysis reported that intermittent cyclical etidronate $(400 \mathrm{mg} / \mathrm{d}$ for $14 \mathrm{~d}$, followed by $500 \mathrm{mg}$ calcium daily for $76 \mathrm{~d}$ ) in corticoid treated patients was effective in preventing bone loss, increasing bone mass but with no statistical significance on reduction of fractures ${ }^{[111]}$.

Other bisphosphonate approved for the treatment of osteoporosis in postmenopausal women is the ibandonate in oral dosage of $2.5 \mathrm{mg} / \mathrm{d}$, or intravenous dosage of $2 \mathrm{mg}$ every $2 \mathrm{mo}$, or $3 \mathrm{mg}$ every $3 \mathrm{mo}$, had shown to be better than placebo, increasing BMD and reducing bone fractures, with superiority of intravenous regimens ${ }^{[112]}$.

For corticoid-induced osteoporosis, in an open-label, single-center, parallel-group, controlled study, participants received $500 \mathrm{mg} / \mathrm{d}$ calcium plus either 3-montly intravenous injections of $2 \mathrm{mg}$ ibandronate or oral $1 \mathrm{mg} / \mathrm{d}$ alfacalcidol for 3 years, showing that the increase in BMD was much greater and the fractures were lower in the ibandronate than those in alfacalcidol group ${ }^{[13]}$.
For the treatment of osteoporosis in IBD, bisphosphonates have been evaluated in few studies. In a 12-mo double-blind, randomized, placebo-controlled study of $10-\mathrm{mg}$ daily dose of alendronate, that include 32 patients with CD in remission and without glucocorticoid treatment the $\mathrm{BMD}$ of the lumbar spine increased $4.6 \% \pm 1.2 \%$ versus a decrease of $0.9 \% \pm 1.0 \%$ in the placebo group $(P<0.01)$. BMD of the hip increased $3.3 \% \pm 1.5 \%$ vs an increase of $0.7 \% \pm 1.1 \%$ in the placebo group $(P<0.08)^{[114]}$.

In 31 patients with $\mathrm{CD}$ and 30 with $\mathrm{UC}$, in a doubleblind placebo-controlled study, all taking $600 \mathrm{mg}$ daily of calcium, after 1 year in the risedronate group the BMD of the spine and hip significantly increase in $2 \%$ and $1.9 \%$, respectively ${ }^{[115]}$. After one year of monthly infusions of $30 \mathrm{mg}$ iv pamidronate plus $500 \mathrm{mg}$ calcium with $400 \mathrm{IU}$ vitamin $\mathrm{D}$ in patients with $\mathrm{CD}$, the $\mathrm{BMD}$ increased $2.6 \%$ (95\% CI: $1.4-3.0)$ at the spine and 1.6\% (95\% CI: 0.6-2.5) at the hip versus $1.6 \%(95 \% \mathrm{CI}: 0.1-3.2)$ at the spine and $0.9 \%$ (95\% CI: 0.4-2.1) at the hip in the group with vitamin D and calcium supplements ${ }^{[116]}$. Stokker PC et al ${ }^{[117]}$ reported a significant improve in $\mathrm{T}$ scores of lumbar spine and hip in 49 patients with IBD that received $30 \mathrm{mg}$ iv pamidronate every $3 \mathrm{mo}$, plus $1000 \mathrm{mg}$ of calcium and 400 IU of vitamin D daily.

\section{Estrogens}

Estrogens alone or with progestin stop progression of bone loss in postmenopausal women, increasing the BMD and reducing the incidence of spine and hip fractures by $34 \%{ }^{[118]}$. Good response in preventing bone loss in patients under glucocorticoid treatment has been observed but the effect on prevention of bone fractures remains unclear, estrogens are not recommended for this purpose ${ }^{[119,120]}$.

Raloxifene, a selective estrogen receptor modulator was approved for the prevention and treatment of postmenopausal spinal osteoporosis. In a meta-analysis of 7 clinical studies, raloxifene reduced the risk of vertebral fractures by $40 \%$ with a dose of $60 \mathrm{mg} / \mathrm{d}^{[121]}$. No studies with raloxifene have done yet in IBD patients.

\section{EMERGENT THERAPIES}

\section{Calcitonin}

Calcitonin intranasal spray, at doses of $200 \mathrm{IU} / \mathrm{d}$ plus $1000 \mathrm{mg}$ calcium and $400 \mathrm{IU}$ vitamin D, has been reported to reduce the risk of spine fractures by $33 \%$ in a 5 -year follow-up time in postmenopausal women ${ }^{[122]}$.

The efficacy of calcitonin for fracture prevention in steroid-induced osteoporosis remains to be established $^{[123,124]}$. No studies have done for IBD-associated osteoporosis.

\section{Teriparatide}

The genetically engineered fragment of human parathyroid hormone, Teriparatide, stimulates new bone formation, leading to increased BMD. Teriparatide, at 20 and 40 micrograms daily subcutaneous injection, reduced the risk of vertebral and non-vertebral fractures in postmenopausal women $^{[125]}$. It's also approved for FDA to increase bone mass in men with primary or hypogonadal osteoporosis ${ }^{[126]}$. 
The efficacy of teriparatide in preventing of treating glucocorticoid-induced or IBD-associated osteoporosis remains to be assessed. Hodsman $\mathrm{AB}^{[127]}$ suggests that should be considered as treatment for patients with established glucocorticiod-induced osteoporosis who require long-term steroid treatment.

\section{CONCLUSION}

IBD has been associated with an increased risk of osteoporosis and osteopenia and epidemiologic studies have reported an increased prevalence of low bone mass in patients with IBD. While genetics play important role, there are other factors in the pathogenesis that play an important interaction and together with environmental influence lead to the an intriguing multifactorial pathogenesis that still has gaps to be fulfilled. Through the knowledge and understanding of basic aspects of bone disease in an autoimmune gastrointestinal scenario we can find leads to a better clinical performance and to bear new diagnostic techniques and breakthrough therapies for a better outcome in IBD patients.

\section{REFERENCES}

1 van Staa TP, Cooper C, Brusse LS, Leufkens H, Javaid MK, Arden NK. Inflammatory bowel disease and the risk of fracture. Gastroenterology 2003; 125: 1591-1597

2 Bernstein CN, Blanchard JF, Leslie W, Wajda A, Yu BN. The incidence of fracture among patients with inflammatory bowel disease. A population-based cohort study. Ann Intern Med 2000; 133: 795-799

3 Loftus EV Jr, Crowson CS, Sandborn WJ, Tremaine WJ, O'Fallon WM, Melton LJ 3rd. Long-term fracture risk in patients with Crohn's disease: a population-based study in Olmsted County, Minnesota. Gastroenterology 2002; 123: 468-475

4 Loftus EV Jr, Achenbach SJ, Sandborn WJ, Tremaine WJ, Oberg AL, Melton LJ 3rd. Risk of fracture in ulcerative colitis: a population-based study from Olmsted County, Minnesota. Clin Gastroenterol Hepatol 2003; 1: 465-473

5 Vestergaard P, Mosekilde L. Fracture risk in patients with celiac Disease, Crohn's disease, and ulcerative colitis: a nationwide follow-up study of 16,416 patients in Denmark. Am J Epidemiol 2002; 156: 1-10

6 Bernstein CN, Leslie WD, Leboff MS. AGA technical review on osteoporosis in gastrointestinal diseases. Gastroenterology 2003; 124: 795-841

7 Vestergaard P, Krogh K, Rejnmark L, Laurberg S, Mosekilde L. Fracture risk is increased in Crohn's disease, but not in ulcerative colitis. Gut 2000; 46: 176-181

8 Jahnsen J, Falch JA, Aadland E, Mowinckel P. Bone mineral density is reduced in patients with Crohn's disease but not in patients with ulcerative colitis: a population based study. Gut 1997; 40: 313-319

9 Ghosh S, Cowen S, Hannan WJ, Ferguson A. Low bone mineral density in Crohn's disease, but not in ulcerative colitis, at diagnosis. Gastroenterology 1994; 107: 1031-1039

10 Andreassen H, Hylander E, Rix M. Gender, age, and body weight are the major predictive factors for bone mineral density in Crohn's disease: a case-control cross-sectional study of 113 patients. Am J Gastroenterol 1999; 94: 824-828

11 Clements D, Motley RJ, Evans WD, Harries AD, Rhodes J, Coles RJ, Compston JE. Longitudinal study of cortical bone loss in patients with inflammatory bowel disease. Scand J Gastroenterol 1992; 27: 1055-1060

12 Roux C, Abitbol V, Chaussade S, Kolta S, Guillemant S, Dougados M, Amor B, Couturier D. Bone loss in patients with inflammatory bowel disease: a prospective study. Osteoporos Int 1995; 5: 156-160

13 Bjarnason I, Macpherson A, Mackintosh C, Buxton-Thomas M, Forgacs I, Moniz C. Reduced bone density in patients with inflammatory bowel disease. Gut 1997; 40: 228-233

14 Pollak RD, Karmeli F, Eliakim R, Ackerman Z, Tabb K, Rachmilewitz D. Femoral neck osteopenia in patients with inflammatory bowel disease. Am J Gastroenterol 1998; 93 1483-1490

15 Stockbrugger RW, Schoon EJ, Bollani S, Mills PR, Israeli E, Landgraf L, Felsenberg D, Ljunghall S, Nygard G, Persson T, Graffner H, Bianchi Porro G, Ferguson A. Discordance between the degree of osteopenia and the prevalence of spontaneous vertebral fractures in Crohn's disease. Aliment Pharmacol Ther 2002; 16: 1519-1527

16 Hussain MM, Strickland DK, Bakillah A. The mammalian low-density lipoprotein receptor family. Annu Rev Nutr 1999; 19: $141-172$

17 Brown SD, Twells RC, Hey PJ, Cox RD, Levy ER, Soderman AR, Metzker ML, Caskey CT, Todd JA, Hess JF. Isolation and characterization of LRP6, a novel member of the low density lipoprotein receptor gene family. Biochem Biophys Res Commun 1998; 248: 879-888

18 Gong Y, Slee RB, Fukai N, Rawadi G, Roman-Roman S, Reginato AM, Wang H, Cundy T, Glorieux FH, Lev D, Zacharin M, Oexle K, Marcelino J, Suwairi W, Heeger S, Sabatakos G, Apte S, Adkins WN, Allgrove J, Arslan-Kirchner M, Batch JA, Beighton P, Black GC, Boles RG, Boon LM, Borrone C, Brunner HG, Carle GF, Dallapiccola B, De Paepe A, Floege B, Halfhide ML, Hall B, Hennekam RC, Hirose T, Jans A, Jüppner H, Kim CA, Keppler-Noreuil K, Kohlschuetter A, LaCombe D, Lambert M, Lemyre E, Letteboer T, Peltonen L, Ramesar RS, Romanengo M, Somer H, Steichen-Gersdorf E, Steinmann B, Sullivan B, Superti-Furga A, Swoboda W, van den Boogaard MJ, Van Hul W, Vikkula M, Votruba M, Zabel B, Garcia T, Baron R, Olsen BR, Warman ML. LDL receptor-related protein 5 (LRP5) affects bone accrual and eye development. Cell 2001; 107: 513-523

19 Little RD, Carulli JP, Del Mastro RG, Dupuis J, Osborne M, Folz C, Manning SP, Swain PM, Zhao SC, Eustace B, Lappe MM, Spitzer L, Zweier S, Braunschweiger K, Benchekroun Y, $\mathrm{Hu}$ X, Adair R, Chee L, FitzGerald MG, Tulig C, Caruso A, Tzellas N, Bawa A, Franklin B, McGuire S, Nogues X, Gong G, Allen KM, Anisowicz A, Morales AJ, Lomedico PT, Recker SM, Van Eerdewegh P, Recker RR, Johnson ML. A mutation in the LDL receptor-related protein 5 gene results in the autosomal dominant high-bone-mass trait. Am J Hum Genet 2002; 70: 11-19

20 Gong Y, Vikkula M, Boon L, Liu J, Beighton P, Ramesar R, Peltonen L, Somer H, Hirose T, Dallapiccola B, De Paepe A, Swoboda W, Zabel B, Superti-Furga A, Steinmann B, Brunner HG, Jans A, Boles RG, Adkins W, van den Boogaard MJ, Olsen BR, Warman ML. Osteoporosis-pseudoglioma syndrome, a disorder affecting skeletal strength and vision, is assigned to chromosome region 11q12-13. Am J Hum Genet 1996; 59: 146-151

21 Xiong DH, Lei SF, Yang F, Wang L, Peng YM, Wang W, Recker RR, Deng HW. Low-density lipoprotein receptorrelated protein 5 (LRP5) gene polymorphisms are associated with bone mass in both Chinese and whites. J Bone Miner Res 2007; 22: 385-393

22 Ezura Y, Nakajima T, Urano T, Sudo Y, Kajita M, Yoshida $\mathrm{H}_{\text {, }}$ Suzuki T, Hosoi T, Inoue S, Shiraki M, Emi M. Association of a single-nucleotide variation (A1330V) in the low-density lipoprotein receptor-related protein 5 gene (LRP5) with bone mineral density in adult Japanese women. Bone 2007; 40: 997-1005

23 Saarinen A, Välimäki VV, Välimäki MJ, Löyttyniemi E, Auro K, Uusen P, Kuris M, Lehesjoki AE, Mäkitie O. The A1330V polymorphism of the low-density lipoprotein receptor-related protein 5 gene (LRP5) associates with low peak bone mass in young healthy men. Bone 2007; 40: 1006-1012

24 Provvedini DM, Tsoukas CD, Deftos LJ, Manolagas SC. 1 
alpha,25-Dihydroxyvitamin D3-binding macromolecules in human B lymphocytes: effects on immunoglobulin production. J Immunol 1986; 136: 2734-2740

25 Speer G, Dworak O, Cseh K, Bori Z, Salamon D, Török I, Winkler G, Vargha P, Nagy Z, Takács I, Kucsera M, Lakatos P. Vitamin D receptor gene BsmI polymorphism correlates with erbB-2/HER-2 expression in human rectal cancer. Oncology 2000; 58: 242-247

26 Ferrari S, Rizzoli R, Manen D, Slosman D, Bonjour JP. Vitamin $\mathrm{D}$ receptor gene start codon polymorphisms (FokI) and bone mineral density: interaction with age, dietary calcium, and 3'-end region polymorphisms. J Bone Miner Res 1998; 13: 925-930

27 Kobayashi T, Sugimoto T, Kobayashi A, Chihara K. Vitamin $\mathrm{D}$ receptor genotype is associated with cortical bone loss in Japanese patients with primary hyperparathyroidism. Endocr J 1998; 45: 123-125

28 Marc J, Prezelj J, Komel R, Kocijancic A. Association of vitamin $\mathrm{D}$ receptor gene polymorphism with bone mineral density in Slovenian postmenopausal women. Gynecol Endocrinol 2000; 14: $60-64$

29 Kitamura I, Ando F, Koda M, Okura T, Shimokata H. Effects of the interaction between lean tissue mass and estrogen receptor alpha gene polymorphism on bone mineral density in middle-aged and elderly Japanese. Bone 2007; 40: 1623-1629

30 Riancho JA. Polymorphisms in the CYP19 gene that influence bone mineral density. Pharmacogenomics 2007; 8: 339-352

31 McGuigan FE, Macdonald HM, Bassiti A, Farmer R, Bear S, Stewart A, Black A, Fraser WD, Welsh F, Reid DM, Ralston $\mathrm{SH}$. Large-scale population-based study shows no association between common polymorphisms of the TGFB1 gene and BMD in women. J Bone Miner Res 2007; 22: 195-202

32 Gorai I, Inada M, Morinaga H, Uchiyama $Y$, Yamauchi $H$, Hirahara F, Chaki O. CYP17 and COMT gene polymorphisms can influence bone directly, or indirectly through their effects on endogenous sex steroids, in postmenopausal Japanese women. Bone 2007; 40: 28-36

33 Napoli N, Villareal DT, Mumm S, Halstead L, Sheikh S, Cagaanan M, Rini GB, Armamento-Villareal R. Effect of CYP1A1 gene polymorphisms on estrogen metabolism and bone density. J Bone Miner Res 2005; 20: 232-239

34 Ezura Y, Nakajima T, Kajita M, Ishida R, Inoue S, Yoshida H, Suzuki T, Shiraki M, Hosoi T, Orimo H, Emi M. Association of molecular variants, haplotypes, and linkage disequilibrium within the human vitamin D-binding protein (DBP) gene with postmenopausal bone mineral density. J Bone Miner Res 2003; 18: $1642-1649$

35 Dennison EM, Syddall HE, Rodriguez S, Voropanov A, Day IN, Cooper C. Polymorphism in the growth hormone gene, weight in infancy, and adult bone mass. J Clin Endocrinol Metab 2004; 89: 4898-4903

36 Iwasaki H, Emi M, Ezura Y, Ishida R, Kajita M, Kodaira M, Yoshida H, Suzuki T, Hosoi T, Inoue S, Shiraki M, Swensen J, Orimo H. Association of a Trp16Ser variation in the gonadotropin releasing hormone signal peptide with bone mineral density, revealed by SNP-dependent PCR typing. Bone 2003; 32: 185-190

37 Langdahl BL, Carstens M, Stenkjaer L, Eriksen EF. Polymorphisms in the transforming growth factor beta 1 gene and osteoporosis. Bone 2003; 32: 297-310

38 Koh JM, Kim DJ, Hong JS, Park JY, Lee KU, Kim SY, Kim GS. Estrogen receptor alpha gene polymorphisms Pvu II and Xba I influence association between leptin receptor gene polymorphism (Gln223Arg) and bone mineral density in young men. Eur J Endocrinol 2002; 147: 777-783

39 Bollerslev J, Wilson SG, Dick IM, Islam FM, Ueland T, Palmer L, Devine A, Prince RL. LRP5 gene polymorphisms predict bone mass and incident fractures in elderly Australian women. Bone 2005; 36: 599-606

40 Yamada Y, Ando F, Niino N, Shimokata H. Association of polymorphisms of interleukin-6, osteocalcin, and vitamin D receptor genes, alone or in combination, with bone mineral density in community-dwelling Japanese women and men. J
Clin Endocrinol Metab 2003; 88: 3372-3378

41 Yamada Y, Ando F, Niino N, Shimokata H. Association of a polymorphism of the CC chemokine receptor-2 gene with bone mineral density. Genomics 2002; 80: 8-12

42 Kornak U, Branger S, Ostertag A, de Vernejoul MC. A VNTR in the CLCN7 gene influences bone density in patients with autosomal dominant osteopetrosis (ADO) type II and in postmenopausal women. J Bone Miner Res 2004; 19: S387

43 Lorentzon M, Eriksson AL, Mellström D, Ohlsson C. The COMT val158met polymorphism is associated with peak BMD in men. J Bone Miner Res 2004; 19: 2005-2011

44 Giraudeau FS, McGinnis RE, Gray IC, O'Brien EJ, Doncaster KE, Spurr NK, Ralston SH, Reid DM, Wood J. Characterization of common genetic variants in cathepsin $\mathrm{K}$ and testing for association with bone mineral density in a large cohort of perimenopausal women from Scotland. J Bone Miner Res 2004; 19: 31-41

45 Yamada Y, Ando F, Niino N, Shimokata H. Association of a polymorphism of the dopamine receptor D4 gene with bone mineral density in Japanese men. J Hum Genet 2003; 48: 629-633

46 Ishida R, Ezura Y, Emi M, Kajita M, Yoshida H, Suzuki T, Hosoi T, Inoue S, Shiraki M, Ito H, Orimo H. Association of a promoter haplotype $(-1542 \mathrm{G} /-525 \mathrm{C})$ in the tumor necrosis factor receptor associated factor-interacting protein gene with low bone mineral density in Japanese women. Bone 2003; 33: 237-241

47 Enattah N, Välimäki VV, Välimäki MJ, Löyttyniemi E, Sahi T, Järvelä I. Molecularly defined lactose malabsorption, peak bone mass and bone turnover rate in young finnish men. Calcif Tissue Int 2004; 75: 488-493

48 Kenny AM, Joseph C, Taxel P, Prestwood KM. Osteoporosis in older men and women. Conn Med 2003; 67: 481-486

49 Yamada Y, Ando F, Niino N, Shimokata H. Association of a polymorphism of the matrix metalloproteinase-1 gene with bone mineral density. Matrix Biol 2002; 21: 389-392

50 Manolagas SC. The role of IL-6 type cytokines and their receptors in bone. Ann N Y Acad Sci 1998; 840: 194-204

51 Schulte C, Dignass AU, Mann K, Goebell H. Bone loss in patients with inflammatory bowel disease is less than expected: a follow-up study. Scand J Gastroenterol 1999; 34: 696-702

52 Keen RW, Woodford-Richens KL, Lanchbury JS, Spector TD. Allelic variation at the interleukin-1 receptor antagonist gene is associated with early postmenopausal bone loss at the spine. Bone 1998; 23: 367-371

53 Giuliani N, Sansoni P, Girasole G, Vescovini R, Passeri G, Passeri M, Pedrazzoni M. Serum interleukin-6, soluble interleukin-6 receptor and soluble gp130 exhibit different patterns of age- and menopause-related changes. Exp Gerontol 2001; 36: 547-557

54 Tsukamoto K, Yoshida H, Watanabe S, Suzuki T, Miyao M, Hosoi T, Orimo H, Emi M. Association of radial bone mineral density with CA repeat polymorphism at the interleukin 6 locus in postmenopausal Japanese women. J Hum Genet 1999; 44: $148-151$

55 Manolagas SC, Kousteni S. Perspective: nonreproductive sites of action of reproductive hormones. Endocrinology 2001; 142 2200-2204

56 Bellido T, Jilka RL, Boyce BF, Girasole G, Broxmeyer H, Dalrymple SA, Murray R, Manolagas SC. Regulation of interleukin-6, osteoclastogenesis, and bone mass by androgens. The role of the androgen receptor. J Clin Invest 1995; 95: 2886-2895

57 Ashcroft AJ, Cruickshank SM, Croucher PI, Perry MJ, Rollinson S, Lippitt JM, Child JA, Dunstan C, Felsburg PJ, Morgan GJ, Carding SR. Colonic dendritic cells, intestinal inflammation, and T cell-mediated bone destruction are modulated by recombinant osteoprotegerin. Immunity 2003; 19: $849-861$

58 Aubin JE, Bonnelye E. Osteoprotegerin and its ligand: a new paradigm for regulation of osteoclastogenesis and bone resorption. Osteoporos Int 2000; 11: 905-913 
59 Kong YY, Boyle WJ, Penninger JM. Osteoprotegerin ligand: a common link between osteoclastogenesis, lymph node formation and lymphocyte development. Immunol Cell Biol 1999; 77: 188-193

60 Kong YY, Feige U, Sarosi I, Bolon B, Tafuri A, Morony S, Capparelli C, Li J, Elliott R, McCabe S, Wong T, Campagnuolo G, Moran E, Bogoch ER, Van G, Nguyen LT, Ohashi PS, Lacey DL, Fish E, Boyle WJ, Penninger JM. Activated T cells regulate bone loss and joint destruction in adjuvant arthritis through osteoprotegerin ligand. Nature 1999; 402: 304-309

61 Kong YY, Penninger JM. Molecular control of bone remodeling and osteoporosis. Exp Gerontol 2000; 35: 947-956

62 Skoumal M, Kolarz G, Haberhauer G, Woloszczuk W, Hawa G, Klingler A. Osteoprotegerin and the receptor activator of NFkappa B ligand in the serum and synovial fluid. A comparison of patients with longstanding rheumatoid arthritis and osteoarthritis. Rheumatol Int 2005; 26: 63-69

63 Skoumal M, Kolarz G, Woloszczuk W, Hawa G, Klingler A. Serum osteoprotegerin but not receptor activator of NFkappaB ligand correlates with Larsen score in rheumatoid arthritis. Ann Rheum Dis 2004; 63: 216-217

64 Szalay F, Hegedus D, Lakatos PL, Tornai I, Bajnok E, Dunkel $\mathrm{K}$, Lakatos P. High serum osteoprotegerin and low RANKL in primary biliary cirrhosis. J Hepatol 2003; 38: 395-400

65 Kong YY, Yoshida H, Sarosi I, Tan HL, Timms E, Capparelli C, Morony S, Oliveira-dos-Santos AJ, Van G, Itie A, Khoo W, Wakeham A, Dunstan CR, Lacey DL, Mak TW, Boyle WJ, Penninger JM. OPGL is a key regulator of osteoclastogenesis, lymphocyte development and lymph-node organogenesis. Nature 1999; 397: 315-323

66 Romas E, Gillespie MT, Martin TJ. Involvement of receptor activator of NFkappaB ligand and tumor necrosis factor-alpha in bone destruction in rheumatoid arthritis. Bone 2002; 30: 340-346

67 Moschen AR, Kaser A, Enrich B, Ludwiczek O, Gabriel M, Obrist P, Wolf AM, Tilg H. The RANKL/OPG system is activated in inflammatory bowel disease and relates to the state of bone loss. Gut 2005; 54: 479-487

68 Steinbuch M, Youket TE, Cohen S. Oral glucocorticoid use is associated with an increased risk of fracture. Osteoporos Int 2004; 15: 323-328

69 Ardizzone S, Bollani S, Bettica P, Bevilacqua M, Molteni P, Bianchi Porro G. Altered bone metabolism in inflammatory bowel disease: there is a difference between Crohn's disease and ulcerative colitis. J Intern Med 2000; 247: 63-70

70 Ulivieri FM, Piodi LP, Taioli E, Lisciandrano D, Ranzi T, Vezzoli M, Cermesoni L, Bianchi P. Bone mineral density and body composition in ulcerative colitis: a six-year follow-up. Osteoporos Int 2001; 12: 343-348

71 Siffledeen JS, Fedorak RN, Siminoski K, Jen H, Vaudan E, Abraham N, Seinhart H, Greenberg G. Bones and Crohn's: risk factors associated with low bone mineral density in patients with Crohn's disease. Inflamm Bowel Dis 2004; 10: 220-228

72 Habtezion A, Silverberg MS, Parkes R, Mikolainis S, Steinhart AH. Risk factors for low bone density in Crohn's disease. Inflamm Bowel Dis 2002; 8: 87-92

73 Jahnsen J, Falch JA, Mowinckel P, Aadland E. Bone mineral density in patients with inflammatory bowel disease: a population-based prospective two-year follow-up study. Scand J Gastroenterol 2004; 39: 145-153

74 Walther F, Fusch C, Radke M, Beckert S, Findeisen A. Osteoporosis in pediatric patients suffering from chronic inflammatory bowel disease with and without steroid treatment. J Pediatr Gastroenterol Nutr 2006; 43: 42-51

75 Haugeberg G, Strand A, Kvien TK, Kirwan JR. Reduced loss of hand bone density with prednisolone in early rheumatoid arthritis: results from a randomized placebo-controlled trial. Arch Intern Med 2005; 165: 1293-1297

76 Haugeberg G, Ørstavik RE, Kvien TK. Effects of rheumatoid arthritis on bone. Curr Opin Rheumatol 2003; 15: 469-475

77 Schulte CM, Dignass AU, Goebell H, Röher HD, Schulte KM. Genetic factors determine extent of bone loss in inflammatory bowel disease. Gastroenterology 2000; 119: 909-920

78 Canalis E, Bilezikian JP, Angeli A, Giustina A. Perspectives on glucocorticoid-induced osteoporosis. Bone 2004; 34: 593-598

79 Canalis E. Mechanisms of glucocorticoid action in bone. Curr Osteoporos Rep 2005; 3: 98-102

80 Takuma A, Kaneda T, Sato T, Ninomiya S, Kumegawa M, Hakeda Y. Dexamethasone enhances osteoclast formation synergistically with transforming growth factor-beta by stimulating the priming of osteoclast progenitors for differentiation into osteoclasts. I Biol Chem 2003; 278: 44667-44674

81 Wodarz A, Nusse R. Mechanisms of Wnt signaling in development. Annu Rev Cell Dev Biol 1998; 14: 59-88

82 Bejsovec $\mathbf{A}$. Wnt signaling: an embarrassment of receptors. Curr Biol 2000; 10: R919-R922

83 Kawano Y, Kypta R. Secreted antagonists of the Wnt signalling pathway. J Cell Sci 2003; 116: 2627-2634

84 Johnson ML, Harnish K, Nusse R, Van Hul W. LRP5 and Wnt signaling: a union made for bone. J Bone Miner Res 2004; 19: 1749-1757

85 Westendorf JJ, Kahler RA, Schroeder TM. Wnt signaling in osteoblasts and bone diseases. Gene 2004; 341: 19-39

86 Hu H, Hilton MJ, Tu X, Yu K, Ornitz DM, Long F. Sequential roles of Hedgehog and Wnt signaling in osteoblast development. Development 2005; 132: 49-60

87 Ohnaka K, Tanabe M, Kawate H, Nawata H, Takayanagi R. Glucocorticoid suppresses the canonical Wnt signal in cultured human osteoblasts. Biochem Biophys Res Commun 2005; 329: 177-181

88 De Keyser F, Baeten D, Van den Bosch F, Kruithof E, Verbruggen G, Mielants H, Veys E. Structure-modifying capacity of anti-tumour necrosis factor-alpha therapy in ankylosing spondylitis. Drugs 2004; 64: 2793-2811

89 Buchman AL. Bones and Crohn's: problems and solutions. Inflamm Bowel Dis 1999; 5: 212-227

90 Valentine JF, Sninsky CA. Prevention and treatment of osteoporosis in patients with inflammatory bowel disease. Am J Gastroenterol 1999; 94: 878-883

91 Raisz LG. Clinical practice. Screening for osteoporosis. N Engl J Med 2005; 353: 164-171

92 Kornbluth A, Hayes M, Feldman S, Hunt M, Fried-Boxt E, Lichtiger S, Legnani P, George J, Young J. Do guidelines matter? Implementation of the ACG and AGA osteoporosis screening guidelines in inflammatory bowel disease (IBD) patients who meet the guidelines' criteria. Am J Gastroenterol 2006; 101: 1546-1550

93 Lichtenstein GR, Sands BE, Pazianas M. Prevention and treatment of osteoporosis in inflammatory bowel disease. Inflamm Bowel Dis 2006; 12: 797-813

94 Leib ES, Binkley N, Bilezikian JP, Kendler DL, Lewiecki EM, Petak SM. Position Development Conference of the International Society for Clinical Densitometry. Vancouver, BC, July 15-17, 2005. J Rheumatol 2006; 33: 2319-2321

95 Shea B, Wells G, Cranney A, Zytaruk N, Robinson V, Griffith L, Hamel C, Ortiz Z, Peterson J, Adachi J, Tugwell P, Guyatt G. WITHDRAWN: Calcium supplementation on bone loss in postmenopausal women. Cochrane Database Syst Rev 2006 CD004526

96 Papadimitropoulos E, Wells G, Shea B, Gillespie W, Weaver B, Zytaruk N, Cranney A, Adachi J, Tugwell P, Josse R, Greenwood C, Guyatt G. Meta-analyses of therapies for postmenopausal osteoporosis. VIII: Meta-analysis of the efficacy of vitamin D treatment in preventing osteoporosis in postmenopausal women. Endocr Rev 2002; 23: 560-569

97 Gillespie WJ, Avenell A, Henry DA, O'Connell DL, Robertson J. Vitamin D and vitamin D analogues for preventing fractures associated with involutional and post-menopausal osteoporosis. Cochrane Database Syst Rev 2001: CD000227

98 Jackson RD, LaCroix AZ, Gass M, Wallace RB, Robbins J, Lewis CE, Bassford T, Beresford SA, Black HR, Blanchette P, Bonds DE, Brunner RL, Brzyski RG, Caan B, Cauley JA, Chlebowski RT, Cummings SR, Granek I, Hays J, Heiss G, Hendrix SL, Howard BV, Hsia J, Hubbell FA, Johnson KC, Judd H, Kotchen JM, Kuller LH, Langer RD, Lasser NL, Limacher MC, Ludlam S, Manson JE, Margolis KL, McGowan J, Ockene JK, O'Sullivan MJ, Phillips L, Prentice RL, Sarto GE, 
Stefanick ML, Van Horn L, Wactawski-Wende J, Whitlock E, Anderson GL, Assaf AR, Barad D. Calcium plus vitamin D supplementation and the risk of fractures. N Engl J Med 2006; 354: 669-683

99 Bernstein CN, Seeger LL, Anton PA, Artinian L, Geffrey S, Goodman W, Belin TR, Shanahan F. A randomized, placebocontrolled trial of calcium supplementation for decreased bone density in corticosteroid-using patients with inflammatory bowel disease: a pilot study. Aliment Pharmacol Ther 1996; 10: 777-786

100 Boonen S, Rizzoli R, Meunier PJ, Stone M, Nuki G, Syversen $\mathrm{U}$, Lehtonen-Veromaa M, Lips P, Johnell O, Reginster JY. The need for clinical guidance in the use of calcium and vitamin $\mathrm{D}$ in the management of osteoporosis: a consensus report. Osteoporos Int 2004; 15: 511-519

101 Cranney A, Wells G, Willan A, Griffith L, Zytaruk N, Robinson V, Black D, Adachi J, Shea B, Tugwell P, Guyatt G. Meta-analyses of therapies for postmenopausal osteoporosis. II. Meta-analysis of alendronate for the treatment of postmenopausal women. Endocr Rev 2002; 23: 508-516

102 Cranney A, Tugwell P, Adachi J, Weaver B, Zytaruk N, Papaioannou A, Robinson V, Shea B, Wells G, Guyatt G. Meta-analyses of therapies for postmenopausal osteoporosis. III. Meta-analysis of risedronate for the treatment of postmenopausal osteoporosis. Endocr Rev 2002; 23: 517-523

103 Rosen CJ, Hochberg MC, Bonnick SL, McClung M, Miller P, Broy S, Kagan R, Chen E, Petruschke RA, Thompson DE, de Papp AE. Treatment with once-weekly alendronate $70 \mathrm{mg}$ compared with once-weekly risedronate $35 \mathrm{mg}$ in women with postmenopausal osteoporosis: a randomized double-blind study. J Bone Miner Res 2005; 20: 141-151

104 Hosking D, Adami S, Felsenberg D, Andia JC, Välimäki M, Benhamou L, Reginster JY, Yacik C, Rybak-Feglin A, Petruschke RA, Zaru L, Santora AC. Comparison of change in bone resorption and bone mineral density with once-weekly alendronate and daily risedronate: a randomised, placebocontrolled study. Curr Med Res Opin 2003; 19: 383-394

105 Bonnick S, Saag KG, Kiel DP, McClung M, Hochberg M, Burnett SM, Sebba A, Kagan R, Chen E, Thompson DE, de Papp AE. Comparison of weekly treatment of postmenopausal osteoporosis with alendronate versus risedronate over two years. J Clin Endocrinol Metab 2006; 91: 2631-2637

106 Saag KG, Emkey R, Schnitzer TJ, Brown JP, Hawkins F, Goemaere S, Thamsborg G, Liberman UA, Delmas PD, Malice MP, Czachur M, Daifotis AG. Alendronate for the prevention and treatment of glucocorticoid-induced osteoporosis. Glucocorticoid-Induced Osteoporosis Intervention Study Group. N Engl J Med 1998; 339: 292-299

107 Adachi JD, Saag KG, Delmas PD, Liberman UA, Emkey RD, Seeman E, Lane NE, Kaufman JM, Poubelle PE, Hawkins F, Correa-Rotter R, Menkes CJ, Rodriguez-Portales JA, Schnitzer TJ, Block JA, Wing J, McIlwain HH, Westhovens R, Brown J, Melo-Gomes JA, Gruber BL, Yanover MJ, Leite MO, Siminoski KG, Nevitt MC, Sharp JT, Malice MP, Dumortier T, Czachur M, Carofano W, Daifotis A. Two-year effects of alendronate on bone mineral density and vertebral fracture in patients receiving glucocorticoids: a randomized, double-blind, placebo-controlled extension trial. Arthritis Rheum 2001; 44: 202-211

108 Wallach S, Cohen S, Reid DM, Hughes RA, Hosking DJ, Laan RF, Doherty SM, Maricic M, Rosen C, Brown J, Barton I, Chines AA. Effects of risedronate treatment on bone density and vertebral fracture in patients on corticosteroid therapy. Calcif Tissue Int 2000; 67: 277-285

109 Cohen S, Levy RM, Keller M, Boling E, Emkey RD, Greenwald M, Zizic TM, Wallach S, Sewell KL, Lukert BP, Axelrod DW, Chines AA. Risedronate therapy prevents corticosteroidinduced bone loss: a twelve-month, multicenter, randomized, double-blind, placebo-controlled, parallel-group study. Arthritis Rheum 1999; 42: 2309-2318

110 Cranney A, Welch V, Adachi JD, Guyatt G, Krolicki N, Griffith L, Shea B, Tugwell P, Wells G. Etidronate for treating and preventing postmenopausal osteoporosis. Cochrane Database
Syst Rev 2001: CD003376

111 Adachi JD, Roux C, Pitt PI, Cooper C, Moniz C, Dequeker J, Ioannidis G, Cawley MI, Jenkins EA, Walker-Bone KE, Pack S, Stephenson GF, Laan RF, Brown J, Geusens P. A pooled data analysis on the use of intermittent cyclical etidronate therapy for the prevention and treatment of corticosteroid induced bone loss. J Rheumatol 2000; 27:2424-2431

112 Delmas PD, Adami S, Strugala C, Stakkestad JA, Reginster JY, Felsenberg D, Christiansen C, Civitelli R, Drezner MK, Recker RR, Bolognese M, Hughes C, Masanauskaite D, Ward $\mathrm{P}$, Sambrook P, Reid DM. Intravenous ibandronate injections in postmenopausal women with osteoporosis: one-year results from the dosing intravenous administration study. Arthritis Rheum 2006; 54: 1838-1846

113 Ringe JD, Dorst A, Faber H, Ibach K, Sorenson F. Intermittent intravenous ibandronate injections reduce vertebral fracture risk in corticosteroid-induced osteoporosis: results from a long-term comparative study. Osteoporos Int 2003; 14: 801-807

114 Haderslev KV, Tjellesen L, Sorensen HA, Staun M. Alendronate increases lumbar spine bone mineral density in patients with Crohn's disease. Gastroenterology 2000; 119: 639-646

115 Henderson S, Hoffman N, Prince R. A double-blind placebocontrolled study of the effects of the bisphosphonate risedronate on bone mass in patients with inflammatory bowel disease. Am J Gastroenterol 2006; 101: 119-123

116 Bartram SA, Peaston RT, Rawlings DJ, Francis RM, Thompson NP. A randomized controlled trial of calcium with vitamin $\mathrm{D}$, alone or in combination with intravenous pamidronate, for the treatment of low bone mineral density associated with Crohn's disease. Aliment Pharmacol Ther 2003; 18: 1121-1127

117 Stokkers PC, Deley M, Van Der Spek M, Verberne HJ, Van Deventer SJ, Hommes DW. Intravenous pamidronate in combination with calcium and vitamin D: highly effective in the treatment of low bone mineral density in inflammatory bowel disease. Scand J Gastroenterol 2006; 41: 200-204

118 Rossouw JE, Anderson GL, Prentice RL, LaCroix AZ, Kooperberg C, Stefanick ML, Jackson RD, Beresford SA, Howard BV, Johnson KC, Kotchen JM, Ockene J. Risks and benefits of estrogen plus progestin in healthy postmenopausal women: principal results From the Women's Health Initiative randomized controlled trial. JAMA 2002; 288: 321-333

119 Lukert BP, Johnson BE, Robinson RG. Estrogen and progesterone replacement therapy reduces glucocorticoidinduced bone loss. J Bone Miner Res 1992; 7: 1063-1069

120 Clements D, Compston JE, Evans WD, Rhodes J. Hormone replacement therapy prevents bone loss in patients with inflammatory bowel disease. Gut 1993; 34: 1543-1546

121 Seeman E, Crans GG, Diez-Perez A, Pinette KV, Delmas PD. Anti-vertebral fracture efficacy of raloxifene: a meta-analysis. Osteoporos Int 2006; 17: 313-316

122 Chesnut CH 3rd, Silverman S, Andriano K, Genant H, Gimona A, Harris S, Kiel D, LeBoff M, Maricic M, Miller P, Moniz C, Peacock M, Richardson P, Watts N, Baylink D. A randomized trial of nasal spray salmon calcitonin in postmenopausal women with established osteoporosis: the prevent recurrence of osteoporotic fractures study. PROOF Study Group. Am J Med 2000; 109: 267-276

123 Cranney A, Welch V, Adachi JD, Homik J, Shea B, SuarezAlmazor ME, Tugwell P, Wells G. Calcitonin for the treatment and prevention of corticosteroid-induced osteoporosis. Cochrane Database Syst Rev 2000: CD001983

124 Cranney A, Welch V, Adachi JD. Calcitonin for preventing and treating corticosteroid-induced osteoporosis: the Cochrane Collaboration. Cochrane Library 2005; 1: 1-31

125 Neer RM, Arnaud CD, Zanchetta JR, Prince R, Gaich GA, Reginster JY, Hodsman AB, Eriksen EF, Ish-Shalom S, Genant HK, Wang O, Mitlak BH. Effect of parathyroid hormone (1-34) on fractures and bone mineral density in postmenopausal women with osteoporosis. N Engl J Med 2001; 344: 1434-1441

126 Orwoll ES, Scheele WH, Paul S, Adami S, Syversen U, DiezPerez A, Kaufman JM, Clancy AD, Gaich GA. The effect of teriparatide [human parathyroid hormone (1-34)] therapy on 
bone density in men with osteoporosis. J Bone Miner Res 2003; 18: $9-17$

127 Hodsman AB, Bauer DC, Dempster DW, Dian L, Hanley DA, Harris ST, Kendler DL, McClung MR, Miller PD,
Olszynski WP, Orwoll E, Yuen CK. Parathyroid hormone and teriparatide for the treatment of osteoporosis: a review of the evidence and suggested guidelines for its use. Endocr Rev 2005; 26: 688-703

S- Editor Liu Y L- Editor Alpini GD E- Editor Lu W 